\title{
DEVELOPMENT OF SOCIAL EDUCATION LEARNING MATERIALS BASED ON LOCAL WISDOM
}

\author{
Aris Suherman \\ IAIN Syekh Nurjati Cirebon \\ Arissuherman60@gmail.com
}

\begin{abstract}
Learning is always interesting to be researched. Learning is a process of active behavior, interactive and constructive when the learning process is used as a social context that needs attention. Social studies learning must be able to become and strengthen the values of local wisdom as a symbol of the students' character identities. Then there needs to be analyzed the pattern of the development of social science learning materials based on the local wisdom in an effort to shape students' characters.

The purpose of this study is to describe the pattern of the development of social science teaching materials based on the local wisdom. This research was conducted in two approaches, qualitative and quantitative, using two patterns, namely: The Dominant-Lessdominant-Design and the development research design,by carrying out four stages, namely: 1) Initial studies, 2) Preparation of teaching materials, 3) Development of teaching materials and 4) Implementation. The techniques of collectingdata of this research were interviews, questionnaires, observations, tests and documentation. The results of this study can be concluded: 1) The development of social science learning materials based on local wisdom can help teachers to understand students and connect learning materials with the region potentials, 2) The development of social studies learning materials based on local wisdom can help students to understand the potential of their area. This can be seen in the acquisition of research results, the average of pre-test score is 33.70, the average of post-test score is 55.80, there was an increase average about0.35. It is in the sufficient categorized.
\end{abstract}

\section{Keywords : Local wisdom, social studies, learning materials.}

\begin{abstract}
ABSTRAK
Pembelajaran merupakan persoalan yang senantiasa menarik untuk dilakukan penelitian. Pembelajaran adalah sebagai proses prilaku aktif, interaktif dan konstruktif manakala proses pembelajaran ini dijadikan sebagai kontekssosial yang perlu mendapat perhatian. Pembelajaran IPS harus mampu menjadi dan menguatkan nilai-nilai kearifan local sebagai symbol identitas karakter anak didik. Maka perlu adanya analisa pola pengembangan materibahan ajar pembelajaran IPS berbasis kearifan local dalam upaya pembentukan karakter siswa.

Tujuan dari penelitian ini adalah untuk mendiskripsikan pola pengembanagn bahan ajar pendidikan IPS berbasis kearifan lokal. Penelitian ini dilakukan dua pendekatan yaitu kualitatif dan kuantitatif dengan menggunakan dua pola yaitu: The Dominant-Less-Desaign dan Desaign research and development. Dengan melakukan empat tahapan yaitu : 1) Studi awal, 2) Penyusunan bahan ajar, 3) Pengembangan
\end{abstract}


materi bahan ajar dan 4) Implementasi. Teknik pengumpulan data penelitian ini yaitu dengan wawancara, kuesioner, observasi, tes dan dokumentasi. Hasil penelitian ini dapat disimpulkan: 1) Pengembangan materi pembelajaran IPS berbasis kearifan local dapat membantu guru dalam upaya pemahaman siswa dan menghubungkan materi pembelajaran dengan potensi wilayah. 2) Pengembangan materi bahan ajar pembelajaran IPS berbasis kearifan local dapat membantu siswa terhadap peningkatan pemahaman potensi daerahnya. Hal ini dapat dilihat pada perolehan hasil penelitian yaitu: dari rata-rata skor pree test 33.70 menjadi 55.80. Ada peningkatan rata-rata 0.35 , walaupun pada kategori cukup atau sedang.

\section{Kata Kunci :Kearifan lokal, Ilmu Pengetahuan Sosial, Materi pembelajaran.}

\section{A. INTRODUCTION}

Learning development by paying attention to the foundation of local culture or called local wisdom will have a greater impact on the development of social studies learning and at the same time give attention to students' concern for the use of the surrounding environment. In the effort to develop social studies learning based on wisdom is the basis of ethno-pedagogical theory. The practice of education by developing local knowledge in various needs of the surrounding community. In this theory, local wisdom is a source of innovative behavior in realizing various aspects of community needs. Embodiments of this innovative behavior such as: Economy, agriculture, plantation, art, religion, customs, traditions, government and others that are closely related to the needs of the community. Wisdom is considered necessary and deserves to be used as a basis for the development of education and culture. According Rahyono (2010) "Local wisdom is human intelligence possessed by certain ethnic groups that are obtained through community experience". This means that local wisdom is the result of certain communities through their experiences and not necessarily experienced by other communities. These values will be very strongly attached to a particular society and that value has gone through a long time, throughout the existence of these communities.

The facts prove that the social studies learning process at elementary school does not link at all to the material or concepts taught with the superior potential of the existing local culture. This means that it does not link the learning process with the existing local culture, it only focuses on the available textbooks. On the 
basis of preliminary observations and interviews with teachers (elementary school) Madrasah Ibtidaiyah, ManisKidul State, Jalaksana District, Kuningan, West Java, the data obtained information that the social studies of teachers only use learning resources from textbooks. This means that the teacher is the only source of information in the social studies learning process, it is called Teacher Center. Teaching materials only focus on textbooks as a guide for students and teaching materials or learning materials do not refer to and adopt regional cultural excellence as an embodiment of local wisdom so that the learning process does not arouse and foster students' interest in being care about the utilization and maintenance of the surrounding environment.

Based on the explanation above, the formulation of the problem that needs to be raised is, how the development of social studies learning materials based on local culture at elementary school level, Madrasah Ibtidaiyah (MI) Manis Kidul, Jalaksana, Kuningan, West Java. This research is more focused on the development of teaching materials or learning materials based on local wisdom in local students in grade V Madrasah Ibtidaiyah (MI) In the first semester, it is about understanding the development of competency in historical material, environment, customs, local culture, religion and other traditions in the area of the district, city and province. The purpose of this research is expected to be able to develop social studies teaching materials or materials at the basic level based on local wisdom that can be used as the references in the learning process of Social Education.

\section{B. METHOD}

In this study two approaches were carried out: Qualitative and quantitative approaches using two patterns: The dominant-Less dominant-design and research and development design. Itis used research and development in Education (Educational Research and Development). It is conducted through four stages: the first stage of the preliminary study, the second stage is the preparation of teaching materials or learning materials, the third stage is the development of learning materials and the fourth stage is implementation. The research was conducted for six months, starting in early January until the end of June 2019. This research was 
conducted at the elementary level, Madrasah Ibtidaiyah (MI) Maniskidul, Jalaksana, Kuningan, West Java. The validation stage of the development of teaching materials or learning materials is carried out in class V Madrasah Ibtidaiyah (MI) Maniskidul, Jalaksana, Kuningan with a total of 23 students. Data collection techniques in this research are questionnaire, interviews, observations, tests and documentation. The quantitative data is validited through the triangulation techniques and data analysis with simple statistics. To obtain valid data and have meaningful data, then analyzed with a descriptive qualitative approach. With a descriptive analysis approach, it is obtained in the form of images, photos, reports, biographies, articles, manuals and others used as documentation of research data. During this study a series of data were collected, reduced and verified so that it can be interpreted and given the meaning of the problem found after it is concluded. Verification is done with the aim to increase the number of interpretations. At this stage a trial was also conducted in class $\mathrm{V}$ of Madrasah Ibtidaiyah students in Maniskidul, Jalaksana, Kuningan to find out how much students' understand the materials or concepts used as teaching material and development was carried out by measuring the capacity to increase the results of pre-test and post-test. The formula used in this research is using the Hake theory formula (Meltzer, 2002).

With the magnitude of the increase in the index gains criteria $(\mathrm{g})$

$$
\begin{array}{ll}
9>0.9 & =\text { High } \\
0.4<9 \leq 0.9 & =\text { Medium } \\
9 \leq 0.4 & =\text { Low }
\end{array}
$$

\section{RESULTS AND DISCUSSION}

The results of the implementation of this study, obtained several findings and information that serve as a reference to develop teaching materials or social studies learning materials based on local wisdom that are carried out at elementary school level, Madrasah IbtidaiyahNegerigrade V Maniskidul, Jalaksana, Kuningan. For more details can be seen in the following systematic explanation.

\section{Preliminary Study}

In this preliminary study, researcher conducted an analysis of the substance of teaching materials in order to get an overview of learning 
materials IPS education began to be packaged and developed through basic competencies in class $\mathrm{V}$ in semester one. Further, explores the potentials of the research study area through literature analysis and literature study in order to obtain data and information on the condition and potential of the area which is used as the research location, the potential of the Kuningan. After conducting a literature study and documentation study, a survey for deepening was carried out using interview and questionnaire techniques for social studies teachers through the assistance of the curriculum development team in the Madrasah IbtidaiyahNegeriManiskidul, Jalaksana, Kuningan. This is done in order to find out the development of social culture-based learning materials (local wisdom). The next is to conduct in-depth study of teaching materials or learning materials with local community leaders in order to obtain the data needed in the effort to develop teaching materials or learning materials based on local wisdom, with interview techniques and documentation studies. So that it can be obtained systematically the development of teaching materials or learning materials based on local wisdom Social Sciences in class V Madrasah Ibtidaiyah in the first semester. Could be seen in the following table:

Table 1

Analysis of Basic Competence Development of Social Studies Learning Materials Based on Local Wisdom Class V Madrasah Ibtidaiyah (MI)

\begin{tabular}{|c|c|c|}
\hline \multicolumn{3}{|c|}{$\begin{array}{l}\text { Analysis of Basic Competence Development of Social Studies Learning Materials } \\
\text { Based on Local Wisdom Class V Madrasah Ibtidaiyah (MI) }\end{array}$} \\
\hline \multicolumn{3}{|c|}{$\begin{array}{l}\text { Understanding History, Embodiments of Surrounding Nature, Natural Environment, } \\
\text { Natural Resources and Social Institutions }\end{array}$} \\
\hline Basic competencies & $\begin{array}{l}\text { Learning Materials / } \\
\text { Materials }\end{array}$ & $\begin{array}{l}\text { Learning Materials / } \\
\text { Materials }\end{array}$ \\
\hline $\begin{array}{l}\text { Have attention to various } \\
\text { historical relics in the } \\
\text { local area (Village, } \\
\text { District, Regency and } \\
\text { Province). And maintain } \\
\text { and preserve it }\end{array}$ & $\begin{array}{l}\text { Various historical relics / } \\
\text { sites in the local area. }\end{array}$ & $\begin{array}{l}\text { History and founding } \\
\text { figures of the city or } \\
\text { district. }\end{array}$ \\
\hline
\end{tabular}




\begin{tabular}{|c|c|c|}
\hline $\begin{array}{l}\text { Read a map of the local } \\
\text { area using a simple } \\
\text { perspective }\end{array}$ & $\begin{array}{l}\text { Read and determine maps } \\
\text { of local environmental } \\
\text { areas }\end{array}$ & $\begin{array}{l}\text { Geographical location, } \\
\text { brass district area and map } \\
\text { of the division of its } \\
\text { territory }\end{array}$ \\
\hline $\begin{array}{l}\text { Describe the natural form } \\
\text { of the regency or city and } \\
\text { provincial environment } \\
\text { and its relation to various } \\
\text { socio-cultural types }\end{array}$ & $\begin{array}{l}\text { Embodiment of the } \\
\text { natural environment in the } \\
\text { local area }\end{array}$ & $\begin{array}{c}\text { Regional attractions, land, } \\
\text { waters and mountains of } \\
\text { the district }\end{array}$ \\
\hline $\begin{array}{l}\text { Show and explain the } \\
\text { various types of } \\
\text { distribution of natural } \\
\text { resources and the } \\
\text { principles of their use for } \\
\text { the economic needs of the } \\
\text { local area }\end{array}$ & $\begin{array}{l}\text { Various types of natural } \\
\text { resources and their } \\
\text { distribution in the local } \\
\text { environmental area }\end{array}$ & $\begin{array}{l}\text { Management and } \\
\text { preservation of various } \\
\text { natural resources in the } \\
\text { Kabutan area }\end{array}$ \\
\hline $\begin{array}{l}\text { Respect cultural norms in } \\
\text { the district and province }\end{array}$ & $\begin{array}{l}\text { Respect the diversity of } \\
\text { local cultural norms }\end{array}$ & $\begin{array}{l}\text { Customs, traditions, arts, } \\
\text { and food characteristics in } \\
\text { the regency }\end{array}$ \\
\hline
\end{tabular}

\section{Preparation of Social Wisdom-Based Social Science Learning Material}

In this second stage, the preparation of social studies learning materials based on local wisdom in class V Madrasah Ibtidaiyah was carried out. The stages of the preparation of learning material that has been presented in this preliminary study are used as guidelines for the preparation of social studies teaching material in the first draft. In this second stage social studies learning materials have been arranged based on local wisdom which will be developed for more basic teaching material materials. The compilation of social studies teaching material materials can be seen in the following table:

\section{Table 2}

\section{Preparation of Social Studies Based Learning Material Learning Materials} Based on Local Wisdom in Class V Madrasah Ibtidaiyah in Semester One 


\begin{tabular}{|c|c|}
\hline $\begin{array}{l}\text { Components of } \\
\text { Teaching Materials }\end{array}$ & Description \\
\hline $\begin{array}{l}\text { Cover Teaching } \\
\text { Materials }\end{array}$ & $\begin{array}{l}\text { On the front page the cover of learning material is made by } \\
\text { giving an overview related to the conditions and potentials } \\
\text { of the Kuningan regency area: the Kuningan Regency Hall, } \\
\text { the Historical Text Building, the Linggarjati Agreement, } \\
\text { the Highest Mountain in West Java, the Ciremai Mountain, } \\
\text { the Darma Reservoir Dam and the Agricultural land. }\end{array}$ \\
\hline $\begin{array}{l}\text { The Substance of } \\
\text { Teaching Materials }\end{array}$ & $\begin{array}{l}\text { The history of the city of brass. The substance of the } \\
\text { material includes the history of the founding of the city of } \\
\text { brass, the royal lineage of the Aryan Kemuning up to the } \\
\text { Head of the Kuningan Regency Pendopo. The natural } \\
\text { manifestation of the Kuningan regency. The substance of } \\
\text { these teaching materials includes: Kuningan regency area, } \\
\text { tourism objects in Kuningan regency area, Kuningan } \\
\text { geographical location, mainland, water and agriculture } \\
\text { area of Kuningan regency. Natural resources. The } \\
\text { substance of these teaching materials includes: Natural } \\
\text { resources in the Kuningan Regency, Management and } \\
\text { Conservation of natural resources in the Kuningan } \\
\text { Regency. Regional culture. The substance of this teaching } \\
\text { material includes: Customs, local traditions, traditional } \\
\text { clothing, local arts, regional specialties and other things in } \\
\text { the Kuningan regency. }\end{array}$ \\
\hline Student worksheet & $\begin{array}{l}\text { Student worksheets are used as media and tools for } \\
\text { students to better understand the teaching material that has } \\
\text { been prepared. }\end{array}$ \\
\hline Competency Test & $\begin{array}{l}\text { Competency test is used to find out and evaluate how far } \\
\text { the understanding and mastery of teaching materials have } \\
\text { been prepared. }\end{array}$ \\
\hline
\end{tabular}

\section{Development of Social Wisdom-Based Social Science Learning Materials}

At this stage of development of social studies teaching material materials, analyzing and assessing the feasibility of a draft of teaching materials that have been arranged to be applied to the learning trials. The next researchers conducted a study of teaching materials in a basic and comprehensive manner, then discussed them and asked for input from experts about the systematic, inland teaching material developed from basic competencies with the potentials of the local area. And also asked for input and opinions of teachers through the curriculum development team in the Madrasah IbtidaiyahNegeriManiskidul, 
Jalaksana, Kuningan. Furthermore, researchers make improvements to teaching materials that have received input from experts and curriculum development team. The next step researchers conducted a limited trial, Namely delivering teaching material to representatives of class V Madrasah Ibtidaiyah students in Maniskidul, Jalaksana, Kuningan which aims to provide input to researcher about the extent of readability and ease of understanding this teaching material that has been compiled. Finally, it can be known the shortcomings, to be made revisions for the perfection of this teaching material. After this instructional material is arranged, validation is then carried out through the application of experimental studies in class. The following is a systematic process of developing social studies teaching material based on local wisdom class $\mathrm{V}$ Madrasah Ibtidaiyah Semester one.

Table 3

Social Science Based Learning Materials for Local Wisdom Semester One Madrasah Ibtidyah

\begin{tabular}{|l|l|l|}
\hline Teaching materials & \multicolumn{1}{|c|}{ Description } & \multicolumn{1}{|c|}{ Repair } \\
\hline / Learning Materials & $\begin{array}{l}\text { On the front page the } \\
\text { cover of learning teaching } \\
\text { material is made by } \\
\text { providing pictures relating } \\
\text { to the conditions and } \\
\text { potentials of the Kuningan } \\
\text { regency area including: } \\
\text { Kuningan regency hall } \\
\text { building, Linggarjati } \\
\text { Agreement Manuscript } \\
\text { Building, Ciremai } \\
\text { Mountain, Darma Dam } \\
\text { the image is adjusted to } \\
\text { the size of the cover page. } \\
\text { and Agriculture District } \\
\text { Region Brass }\end{array}$ & \\
\hline Substance of Materials / \\
Learning Materials
\end{tabular}




\begin{tabular}{|l|l|l|}
\hline & $\begin{array}{l}\text { Arya Kemuning until the } \\
\text { stakeholders in the } \\
\text { Kuningan Regency Hall }\end{array}$ & $\begin{array}{l}\text { sentence structure of } \\
\text { Indonesian which is good. } \\
\text { 2. Adding the role and } \\
\text { function as well as the } \\
\text { royal lineage of the Duke } \\
\text { of Arya Kemuning, } \\
\text { Kuningan District. } \\
\text { 3. Add maps and images } \\
\text { of each royal throne. } \\
\text { 4. Add tomb photo } \\
\text { documentation, patilasan } \\
\text { from the royal throne }\end{array}$ \\
\hline Student worksheet & $\begin{array}{l}\text { At this stage there were no } \\
\text { improvements or revisions } \\
\text { used as a measurement } \\
\text { tool to help students } \\
\text { understand the teaching } \\
\text { materials that have been } \\
\text { prepared }\end{array}$ & $\begin{array}{l}\text { Kopetensis test is used to } \\
\text { find out and evaluate how } \\
\text { far the understanding and } \\
\text { mastery of teaching } \\
\text { materials have been } \\
\text { prepared }\end{array}$ \\
\hline Kopetensis Test & $\begin{array}{l}\text { The improvement at this } \\
\text { stage is the need to add } \\
\text { substance to the questions } \\
\text { because there is an } \\
\text { expansion of the next } \\
\text { learning material. }\end{array}$ \\
\hline
\end{tabular}

4. Implementation of Social Wisdom-Based Social Science Learning Material

Implementation at this stage, that social science learning based on local wisdom is implemented in class V students of Madrasah Ibtidaiyah,Maniscidul, Jalaksana, Kuningan District with 23 students as the sample, using the Pre Experimental Method approach, by using a comparison of scores between pretest scores and post-test scores. The experimental method was carried out by beginning with the provision of the pre-test questions. Furthermore, this learning material was implemented through the application of social studies learning and ended with the administration of the post test. This is done to find out and measure the amount of increased mastery of the material presented. Measurement of this increase is done using the gain index formula (miltzer: 2002). 
It can be obtained the result about some improvement in students' understanding of social science learning materials based on local wisdom. This can be seen in the following table:

\section{Table 4}

\section{Increased of Students' Understanding of Learning Materials} for Social Studies Education Based on Local Wisdom

\begin{tabular}{|c|c|c|c|}
\hline $\begin{array}{c}\text { Average Pree Test } \\
\text { Score }\end{array}$ & $\begin{array}{c}\text { Average Post Test } \\
\text { Score }\end{array}$ & $\begin{array}{c}\text { Average Gain } \\
\text { Score }\end{array}$ & Boost Category \\
\hline 33,70 & 55,80 & 0,35 & Fair / Medium \\
\hline
\end{tabular}

Based on the above analysis, shows an increase in student understanding even though the category is sufficient / medium in learning social science learning teaching materials based on local wisdom. This can be seen in the average score of 33.70 on the Pree test score to 55.80 on the acquisition of the post-test score, with an average gain value index of 0.35 . This indicates an increase even in the moderate / sufficient category. This increase was obtained due to the planning and development of teaching materials for social studies learning materials designed in such a way as to make it easier for students to learn by displaying pictures on the front page or cover on some of the substance of the learning material to make students interested and motivated to understand it. Thus the researcher believes that students are assumed to be able to understand the conditions and potentials that exist in the region. The preparation and development of social studies learning material learning materials based on local wisdom contribute: 1. Providing assistance to teachers to develop social studies teaching and learning materials. 2. Developing respect and mutual respect and being tolerant. 3. Strengthening students' understanding of the importance of maintaining and preserving the region's conditions and potentials.

\section{CONCLUSION}

The results of this study can be summarized as follows: 1. Learning material based on local wisdom in the social studies education can help teachers in developing and connecting learning material with the conditions and potentials, 2 . The development of teaching materials on the social science learning materials 
based on local wisdom can help students to increase understanding of the potentials of the region. This can be seen an increase in students' understanding in learning social science education based on local wisdom, from an average score of pre-test 33.70 and became 55.80 in the post-test.The average post test score improvement is 0.35 , in the medium category.

\section{REFENCES}

Arini, NeniSetia. 2014. Pengaruh Model Klarifikasi Nilai Berbasis Jurnal Terhadap Proses Internalisasi Dalam Pembelajaran IPS. Bandung :Tesis.

Abdullah, Taufik. 2006. Ilmu Sosial Dan Tantangan Zaman. Jakarta : Raja Grafindo Persada

Anwar, Muhammad Khaerul. 2016. Hubungan Antara Konsep Diri Dengan Interaksi Sosial. Universitas Muhamadiyah Surakarta.

Abbas, E. Warmansyah. 2015. Pendidikan IPS Berbasis Kearifan Lokal. Bandung :Wahana Jaya Abadi.

Al-Tabbany, T. I. B. 2014. Mendesain Model Pembelajaran Inovatif, Progresif dan Kontektual. Jakarta :Prenada media Group.

Anggrayni, N.T. 2016. Pendidikan Karakter Berbasis Kearifan Lokal Budaya Jawa. Yogyakarta : Universitas PGRI.

Aris. 2016. Dialog Kreatif Dalam Pembelajaran IPS. Cirebon : CV. LC PRO.

Dadang supardan. 2008. Pengantar Ilmu-ilmu Sosial. Jakarta : PT. BumiAksara.

Elly, M. Dkk. 2006. Ilmu Sosial Budaya Dasar. Jakarta :Kencana.

Faqbeminity. Fasina, F. 2011. The Role Of Parent In Early Childhood Education A Cass Study Of Ikeja, Logos State. Journal Of Human Social Science Volume 11 Issu 2 Version. Covernat University, Ota, Ogunstate Global.

Fredrikksson, ULF. 2014. Quality Education : The key Role Of Teacher, Dalam Education International Working Papers No 14.

Fajarini, Ulfah. 2014. Peranan Kearifan Lokal Dalam Pendidikan Karakter. Jurnal Sosio Didaktika vol. 1. No 2. Jakarta : UIN Syarif Hidayatullah.

Gunawan, Rudi. 2013. Pendidikan IPS Filosofi, Konsep Dan Aplikasi. Bandung :Alfabeta.

Kasim, M. 2002. Pendidikan IPS Filosofis, Konsep Dan Aplikasi. Bandung :Alfabeta.

Mun'in, Fatchur. 2011. Pendidikan Karakter Konstruksi Teoritik Dan Praktik (Urgensi Pendidikan Progresif dan Peran Guru dan Orang Tua). Bandung :Remaja Rosda karya.

Maryani, Nok. 2011. Pengembangan Program Pembelajaran IPS Untuk Peningkatan Keterampilan Sosial. Bandung :Alfabeta. 
Masduki, A. Dkk. 2015. Kearifan Lokal Masyarakat Pangandaran Dalam Mengahadapi Bencana Alam. Bandung :Balai Pelestarian Nilai Budaya.

Nadir. Dkk. 2009. Pendidikan Ilmu Pengetahuan Sosial. Jakarta :Rineka Cipta.

Nasrullah, Rully. 2017. Media Sosial. Bandung :Simbiosa Rekatama Media.

Sugiono. 2010. Metode Penelitian Pendidikan (Pendekatan Kualitatif, Kuantitatif). Bandung :Alfabeta.

Syam, Nina W. 2012. Psikologi Sosial. Bandung :Simbiosa Rekatama Media.

Sardiman. A. M. 2011. Interaksi dan Motivasi Belajar Mengajar. Jakarta : Raja Grafindo Persada.

Sanjaya, Wina. 2008. Strategi Pembelajaran Berorientasi Standar Proses Pendidikan. Jakarta :Kencana Prenada Media Group.

Sudaryono. 2014. Classroom Action Research. Jakarta :Lentera Ilmu Cendekia.

Solihatin dan Raharjo. 2012. Kooperatife Learning :Analisis Pembelajaran IPS. Jakarta : PT. Bumi Aksara.

Susanto, A. 2014. Pengembangan Pembelajaran IPS Di Sekolah Dasar. Jakarta :Prenada media Group.

Suyitno, Imam. 2012. Pengembangan Pendidikan Karakter Dan Budaya Bangsa Berwawasan Kearifan Lokal. Jurnal : Malang FBS Universitas Negeri Malang.

Triyanto. 2011. Model Pembelajaran IPS Terpadu. Bandung : PT. Rosdakarya.

Usman, Husaini. 2009. Metode Penelitian Sosial. Jakarta :Bumi Aksara.

Willyam G. Thompson. 2002. The Effect Of Character Education On Student Behavior. Dessertation. The Faculty Of Departement Of Educational Leadership And Policy Analysis East Temesse State University.

Wahid Murni. 2017. Metodologi Pembelajaran IPS. Yogyakarta :Ar-Ruzz Media.

Westergard Elsa. 2013. Teacher Competences And Parental Couperation. International Journal A Bout Parents In Education. Vol. 7 No 2. University Of Stavenger. Norway.

Yamin, Martinis. 2006. Strategi Pembelajaran Berbasis Kopetensis. Jakarta :Gaung Persada Press. 